\title{
STUDI ZONA SESAR MENGGUNAKAN METODE GEOLISTRIK RESISTIVITAS DAN DATA GEOLOGI PERMUKAAN DI KECAMATAN UJUNGLOE KABUPATEN BULUKUMBA
}

\author{
Muhammad Yusran, Muhammad Altin Massinai, Muhammad Hamzah Syahruddin \\ Departemen Geofisika FMIPA Universitas Hasanauddin, Kampus Tamalanrea 90245, Indonesia. \\ *Corresponding author. Email: myus201413@gmail.com
}

Manuscript received: 28 January 2020; Received in revised form: 20 April 2020; Accepted: 25 April 2020

\begin{abstract}
Abstrak
Kabupaten Bulukumba merupakan salah satu daerah di Sulawesi yang berpotensi mengalami bencana gempabumi karena adanya aktivitas Sesar Walanae. Penelitian ini bertujuan mengetahui (1) keberadaan zona sesar dan gambaran struktur bawah permukaan berdasarkan metode geolistrik pada daerah penelitian dan (2) gambaran struktur geologi permukaan pada daerah penelitian. Identifikasi awal kenampakan sesar di daerah penelitian dimulai dengan analisis citra dari Google Earth, pengamatan lapangan terhadap pencirian sesar, kemudian dilakukan pengukuran menggunakan metode geolistrik resistivitas konfigurasi Wenner-Schlumberger untuk mendapatkan nilai resistivitas untuk setiap perlapisan batuan di bawah permukaan. Pengukuran dilakukan pada dua lintasan yang berbeda dengan panjang lintasan masing-masing $300 \mathrm{~m}$ dan jarak antar elektroda sebesar $5 \mathrm{~m}$. Data - data yang diperoleh diolah dan diinterpretasikan untuk menarik kesimpulan hasil penelitian. Hasil penelitian menunjukkan bahwa terdapat aktivitas sesar di daerah penelitian yang ditandai dengan terbentuknya Lembah Sungai Bijawang, penurunan bidang daratan yang membentuk bidang horst dan graben serta adanya pembelokan yang cukup tajam pada alur sungai dan gawir sesar yang terdapat di sepanjang lembah pada jalur sungai tersebut. Selain itu, berdasarkan hasil pengolahan data geolistrik resistivitas disimpulan bahwa terdapat zona sesar di daerah penelitian berdasarkan interpretasi penampang 2D dari data hasil inversi nilai resistivitas. Struktur perlapisan batuan antara lintasan 1 dan lintasan 2 memiliki karakteristik yang identik sehingga mengindikasikan keterdapatan aktivitas sesar mendatar yang telah memisahkan kedua bidang tersebut. Struktur perlapisan tanah di daerah penelitian di dominasi oleh lapisan lempung berpasir dengan nilai resistivitas berkisar antara $100-400 \Omega \mathrm{m}$ dan $10-200 \Omega \mathrm{m}$.
\end{abstract}

Kata Kunci: geolistrik; struktur geologi; zona sesar.

\begin{abstract}
Bulukumba Regency is a potential area to have an earthquake disaster because of fault activity in the Bulukumba plain. This study aims to determine (1) the existence of fault zone and the description of subsurface structures based on the geoelectric method in the study area and (2) the description of the geological structure in the study area. Identification of faults in the study area began with image analysis from Google Earth, field observations of fault's characteristic, and measurement by resistivity geoelectric method using Wenner-Schlumberger configuration to obtain resistivity values for each layer of rock beneath the surface. Measurements were made on two different lines, length of each line is 300 $\mathrm{m}$ and distance between electrodes is $5 \mathrm{~m}$. The data obtained then processed and interpreted to draw conclusions as the results of the study. The results showed that there was a fault activity in study area which mark by the formation of the Bijawang river valley, a decrease in the land area that formed the horst and graben fields, river deflection and fault escarpment along the valley on the river path. In
\end{abstract}


addition, based on the results of resistivity geoelectric data processing, it concluded that there is a fault zone in the study area based on 2D cross section interpretation of the resistivity value. Rock layering structure between lane 1 and lane 2 has identical characteristics so that it indicates the normal fault activity that has been separate those fields. The structure of soil layers in the study area is dominated by sandy loam layers with resistivity values ranging from $100-400 \Omega \mathrm{m}$ and $10-200 \Omega \mathrm{m}$.

Keywords: fault zone; geoelectric; geological structure.

\section{Pendahuluan}

Indonesia merupakan daerah dengan sesar dan gunung api teraktif di dunia sebagai akibat dari manifestasi tektoniknya (Hamilton, 1979). Pertemuan tiga lempeng besar dunia (Indo-Australia, Eurasia, dan Filipina) menyebabkan daerah ini sangat rawan terhadap bencana gempabumi tektonik, termasuk di Pulau Sulawesi (Pakpahan dkk., 2015).

Selain ketiga lempeng besar tersebut, terdapat pula Lempeng Pasifik di sebelah timur Indonesia yang bergerak dan menabrak sisi utara Papua dan Maluku dengan kecepatan $120 \mathrm{~mm} /$ tahun, sementara Lempeng Indo-Australia yang menunjam di bawah palung laut dalam Sumatera hingga NTT bergerak ke utara dengan kecepatan $50-70 \mathrm{~mm} /$ tahun. (Bock dkk., 2003)

Pergerakan lempeng tektonik di wilayah Indonesia bagian timur lebih cepat dibanding Indonesia bagian barat sehingga wilayah timur Indonesia memiliki potensi ancaman bencana gempabumi dua kali lipat dibandingkan dengan Indonesia bagian barat (Natawidjaya dan Triyoso, 2007).

Beberapa bencana gempabumi besar yang pernah terjadi di Sulawesi diantaranya; gempa berkekuatan M7,8 di Sulawesi Utara pada bulan Agustus 1968, gempa berkekuatan M7,7 di Sulawesi Tengah pada bulan November 2008 (Massinai, 2016), gempa berkekuatan M5,1 di Sulawesi Utara pada bulan Maret 2018 serta beberapa gempa kecil yang berkekuatan di bawah M5,0 yang terjadi hampir sepanjang waktu di seluruh wilayah Pulau Sulawesi.
Gempa besar yang juga terjadi di Sulawesi adalah gempa dengan magnitude M7,7 pada bulan September 2018, pusat gempa berada di $26 \mathrm{~km}$ utara Donggala dan $80 \mathrm{~km}$ barat laut kota Palu Sulawesi Tengah dengan kedalaman $10 \mathrm{~km}$, gempa ini memicu tsunami hingga ketinggian 5 meter di Kota Palu dan guncangan gempabumi dirasakan hingga Kota Balikpapan, Kota Samarinda, dan Kota Makassar. (BMKG, 2018).

Banyaknya kejadian gempa ini disebabkan adanya zona sesar - sesar aktif dengan kedalaman dangkal yang terdapat hampir di seluruh bagian pulau Sulawesi.

Salah satu wilayah di Sulawesi Selatan yang juga berpotensi mengalami bencana kegempaan adalah Kabupaten Bulukumba. Hal ini disebabkan adanya manifestasi Sesar Walanae di daratan Kabupaten Bulukumba. Keberadaannya perlu diketahui guna meminimalkan risiko akibat gempa yang timbul apabila sesar di wilayah ini bergerak.

Data yang diperlukan untuk menganalisis potensi bahaya gempa yang dapat ditimbulkan oleh aktivitas suatu sesar meliputi zona sesar aktif, sebaran, lokasi aktual, dan karakteristik sumber gempa. Hal tersebut perlu diketahui sehingga resiko akibat gempa baik pada batuan dasar maupun tanah permukaan serta mitigasinya dapat diperkirakan.

Letak geografis Kabupaten Bulukumba yang berbatasan dengan zona pemekaran dasar laut Teluk Bone di sebelah timur dan keberadaan Sesar Walanae di daratan Kabupaten Bulukumba menyebabkannya menjadi salah satu wilayah yang berpotensi 
mengalami bencana kegempaan dan tsunami (Massinai dkk., 2017).

Berdasarkan catatan sejarah, gempa yang menimbulkan tsunami besar pernah terjadi di Kabupaten Bulukumba. Gempa tersebut disebabkan oleh adanya aktivitas sesar aktif yang dikenal sebagai Back Arc Thrust (sesar naik belakang busur kepulauan) yang memanjang dari pantai utara Lombok hingga sebelah timur laut Bali. (Pertiwi dkk., 2018).

Selain itu, terdapat pula gempa-pempa kecil dengan magnitude di bawah 4,0 (Massinai, 2016) yang dampaknya tidak terlalu dirasakan, kebanyakan pusat gempa terjadi di laut dengan kedalaman $10 \mathrm{~km}$ sehingga tidak menimbulkan dampak yang berarti di dataran Bulukumba, namun hal ini tetap harus diwaspadai untuk mengantisipasi efek domino yang ditimbulkan dari peristiwa gempa yang bisa membangkitkan aktivitas sesar sehingga dampaknya akan lebih buruk.

Dengan demikian diperlukan suatu kajian mendalam untuk mengetahui keberadaan zona sesar di daerah penelitian, meliputi analisis struktur geologi permukaan dan perlapisan batuan di bawah permukaan menggunakan metode geolistrik resistivitas yang kiranya dapat memberikan gambaran struktur perlapisan batuan yang terindikasi sebagai lokasi keberadaan sesar.

\section{Metode Penelitian}

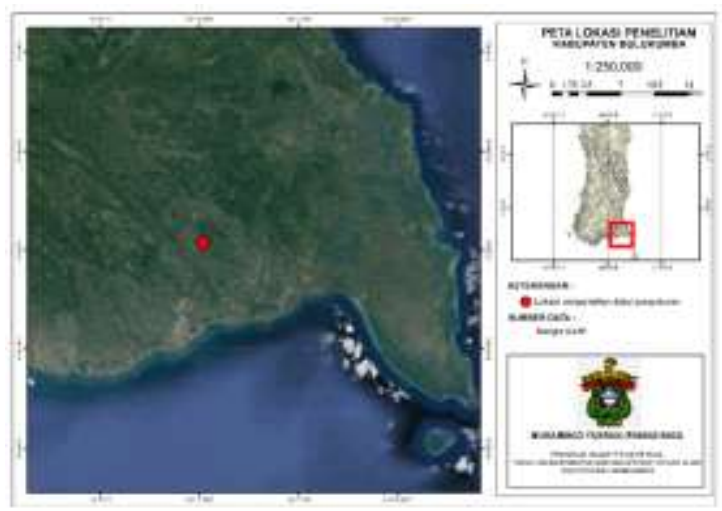

Gambar 1. Peta lokasi penelitian
Penelitian ini dilaksanakan pada tahun 2019. Lokasi penelitian di Kecamatan Ujung Loe, Kabupaten Bulukumba, Sulawesi Selatan (Gambar 1). Data yang diambil penulis berupa data digital hasil rekaman geolistrik (resistivity) dan pengamatan struktur geologi daerah penelitian.

Alat yang digunakan pada penelitian ini yaitu satu set peralatan geolistrik dengan spesifikasi dan kelengkapan sebagai berikut:

1. 1 set peralatan Geolistrik (Geomative GD-10 DC Geo-Electrical Res/IP)

2. 1 unit switchbox dan Batterai DC

3. 1 unit laptop untuk akuisisi data lapangan dan pengolahan data

4. Kabel roll

5. Elektrode stainless steel (60 buah)

6. Palu

7. 1 unit hand GPS dan 1 set toolkit

8. Kompas-klinometer (Brunton)

9. Handy Talky (HT)

10. Meteran

Identifikasi awal di daerah penelitian diawali dengan analisis citra dari Google Earth untuk melihat pencirian sesar yang mungkin nampak, seperti pola kelurusan, pembelokan sungai, atau gawir sesar dan untuk memperoleh gambaran awal lokasi penelitian berdasarkan penampakan pada citra. Selanjutnya data citra digunakan untuk menentukan lokasi kunci pengambilan data lapangan.

Pada lokasi pengukuran yang telah ditentukan dilakukan pengamatan lapangan terhadap geomorfologi permukaan yang berkaitan dengan unsur - unsur pencirian sesar meliputi struktur bidang perlapisan pada singkapan batuan yang dapat diamati secara langsung pada kenampakan kekar atau lipatan.

Selanjutnya dilakukan pengukuran lanjutan menggunakan metode geolistrik resistivitas konfigurasi Wenner-Schlumberger untuk mendapatkan data beda potensial $(\Delta V)$ yang 
timbul akibat beda potensial yang terjadi pada titik - titik pengukuran dan kuat arus listrik $(I)$ yang diinjeksikan ke dalam bumi. Pengukuran dilakukan pada dua lintasan dengan panjang masing-masing lintasan adalah 300 meter. Jarak antar elektroda pada setiap lintasan adalah 5 meter. Sehingga elektroda yang digunakan berjumlah 60 batang untuk setiap lintasan.

Data - data hasil pengukuran yang didapatkan dari lapangan berupa data resistivitas yang tersimpan otomatis pada alat Geomative GD-10 kemudian dipindahkan dari alat dalam bentuk file "dat" ke perangkat komputer/ laptop untuk diolah menggunakan software pengolah data resistivitas $2 \mathrm{D}$ dan diinterpretasikan dengan mengacu pada tabel nilai resistivitas batuan.

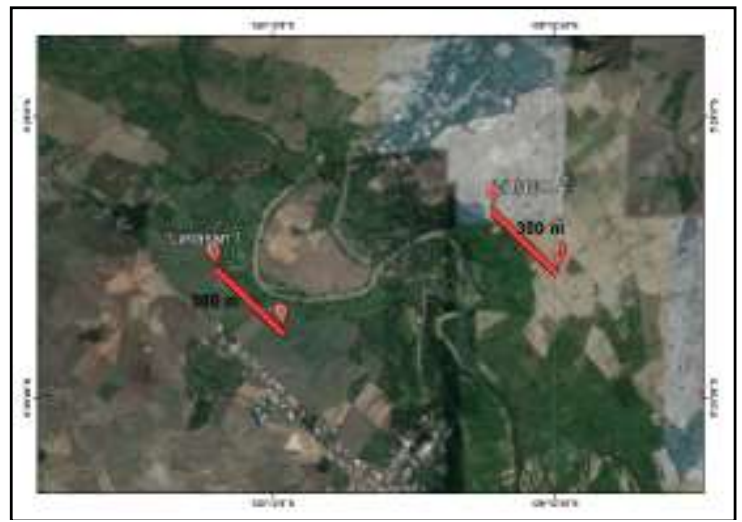

Gambar 2. Daerah lintasan pengukuran berdasarkan manifestasi Google Earth

Secara umum diagram alir dari penelitian ini dapat diuraikan seperti pada gambar 3 berikut:

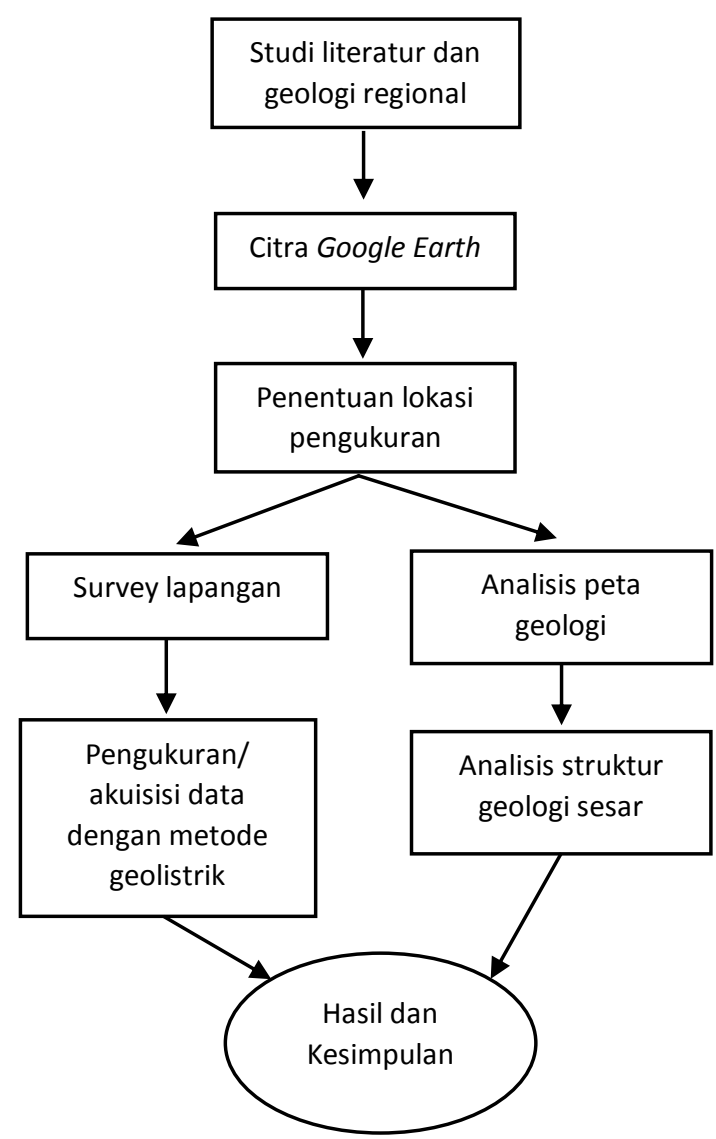

Gambar 3. Diagram alir penelitian

Hasil dari analisis dan interpretasi data pengukuran selanjutnya digunakan untuk memberikan gambaran secara utuh dan kesimpulan dari hasil penelitian.

\section{Hasil dan Pembahasan}

Peta geologi daerah penelitian yang dimodifikasi dari Peta Geologi Lembar Ujung Pandang, Benteng, dan Sinjai skala 1:250.000 dari Rab Sukamto dan Sam Supriatna (1982) ditampilkan pada gambar 4 berikut: 


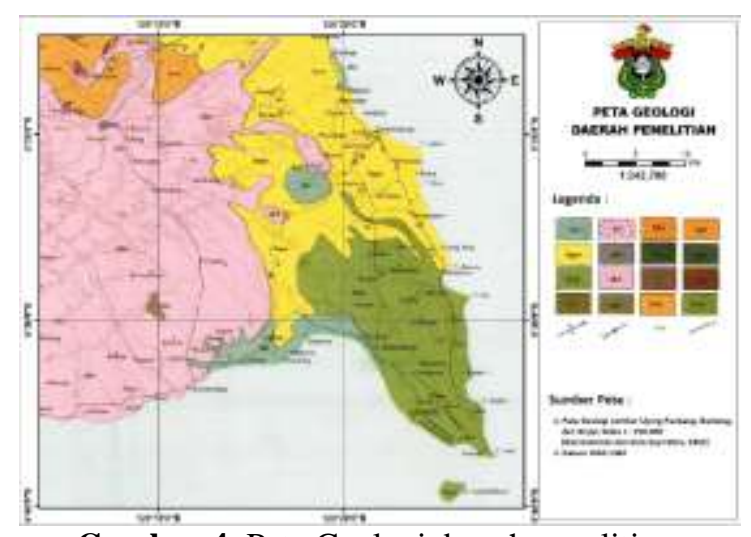

Gambar 4. Peta Geologi daerah penelitian.

Keterangan legenda:

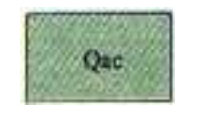

Endapan Aluvium dan Pantai; kerikil, pasir, lempung, lumpur, dan batugamping koral.

\begin{tabular}{|l|}
\hline Impw $: \begin{array}{l}\text { Formasi } \\
\text { batupasir, konglomerat, } \\
\text { tufa, batulanau, } \\
\text { batulempung, } \\
\text { batugamping, napal }\end{array}$
\end{tabular}

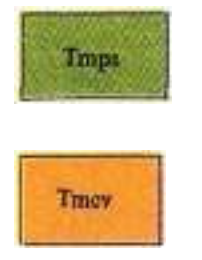

: Anggota Selayar Formasi Walanae; batugamping

: Batuan Gunungapi Formasi Camba; breksi, lava, konglomerat, tufa.

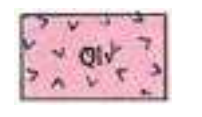

\section{Batuan Gunungapi} Lompobattang; konglomerat, lava, breksi, endapan lahar, tufa

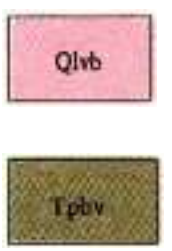

: Terutama breksi, lahar dan tufa

\section{Batuan Gunungapi Baturape-Cindako; lava, breksi, tufa, konglomerat}

Berdasarkan peta geologi tersebut dapat diketahui bahwa stratigrafi wilayah Kabupaten Bulukumpa umumnya terdiri dari Formasi Walanae (Tmpw) yang tersusun dari batupasir, tufa dan konglomerat dengan perselingan batugamping, batulempung, napal, batulanau, dan lignit.

Formasi Walanae (Tmpw) ini merupakan lanjutan dari lembah Sungai Walanae di Lembar Pangkajene dan Watampone Bagian Barat di sebelah utara Kabupaten Bulukumba. Komposisi batuan yang banyak mengandung tufa terdapat di bagian utara, yang banyak mengandung batupasir terdapat di bagian tengah, sementara di bagian selatan batuannya banyak mengandung batu gamping Anggota Selayar (Tmps). Ketebalan Formasi Walanae (Tmpw) ini sekitar $2500 \mathrm{~m}$, membentuk perbukitan dengan ketinggian rata-rata $250 \mathrm{~m}$ di atas permukaan laut dengan kemiringan antara $10^{\circ}-20^{\circ}$.

Selain Formasi Walane (Tmpw), stratigrafi wilayah Kabupaten Bulukumba juga terdiri dari Batuan Gunungapi Lompobattang $(Q l v)$ yang mengandung aglomerat, lava, breksi, endapan lahar dan tufa. Sebagian besar komposisi batuannya merupakan andesit dan basal. Selain itu terdapat lava dengan komposisi yang berlubang - lubang dan ada pula yang berlapis, sementara lapisan breksi dan tufanya mengandung banyak biotit (Sukamto dan Supriatna, 1982).

Komposisi batuan ini dapat pula diamati secara langsung pada singkapan singkapan yang nampak di lokasi penelitian (gambar 5). Sementara itu diperlukan kajian lebih lanjut untuk memperoleh indikasi keberadaan jalur sesar yang melewati daerah penelitian dengan mencari bukti - bukti berupa data geologi permukaan dan pengukuran langsung di lapangan menggunakan metode geolistrik resistivitas untuk mengetahui struktur perlapisan bawah permukaan di daerah tersebut.

Identifikasi awal yang dilakukan dalam adalah melihat geomorfologi atau bentang alam yang tersebar di daerah penelitian. 
Kondisi geomorfologi yang tampak jelas akibat pengaruh tektonik di daerah ini adalah terbentuknya lembah Sungai Bijawang, keberadaan gawir sesar, penurunan bidang daratan yang membentuk bidang horst dan graben dan pembelokan pada alur sungai ini. Adanya pembelokan yang cukup tajam pada alur sungai dan gawir sesar yang terdapat di sepanjang lembah pada jalur sungai dapat diindikasikan sebagai akibat adanya aktivitas sesar mendatar pada area tersebut.

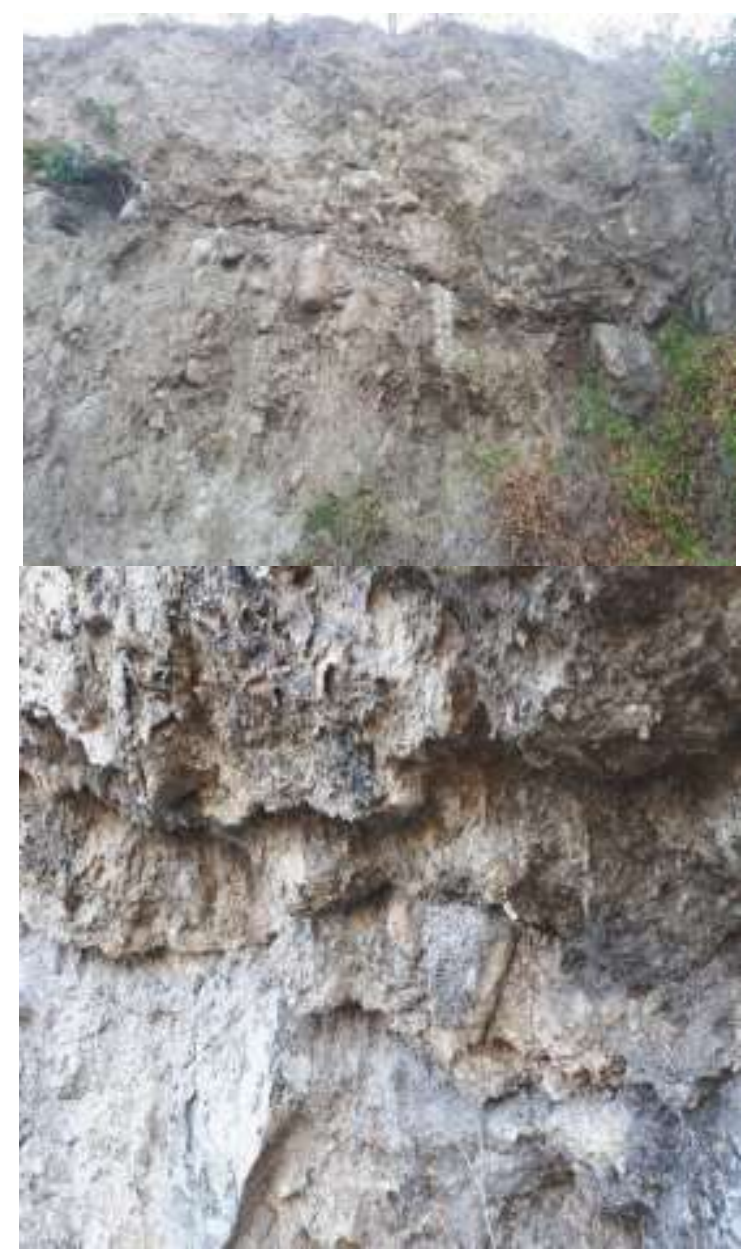

Gambar 5. Singkapan lipatan yang dapat diamati di daerah penelitian.

Adapun hasil pengukuran geolistrik yang telah dilakukan dan diolah menggunakan software pengolah data resistivitas 2D ditampilkan dalam penampang 2D nilai resistivitas batuan berikut:

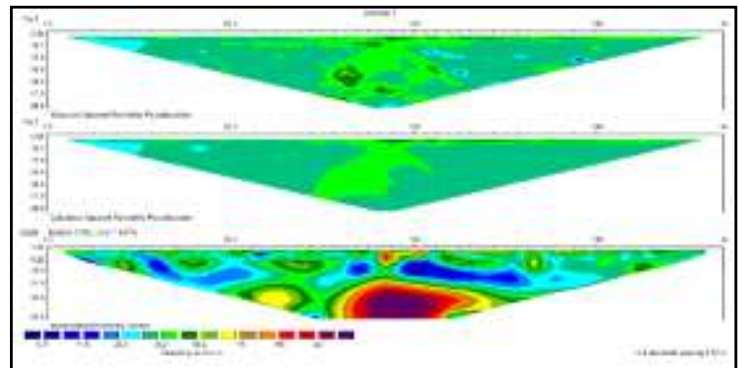

Gambar 6. Penampang 2D harga resistivitas semu dari hasil inversi lintasan 1.

Gambar 6 memperlihatkan penampang resistivitas dengan nilai distribusi resistivitas bawah permukaan dengan nilai RMS Error sebesar 6,9\% yang selanjutnya dapat diinterpretasi dan diketahui jenis perlapisan batuan di bawah permukaan berdasarkan nilai resistivitas jenis semu hasil inversi.

Hasil pengukuran diperoleh nilai resistivitas yang berkisar antara $6-400$ $\Omega \mathrm{m}$. Hal ini menandakan bahwa lintasan pengukuran tersusun dari lapisan sedimen berusia kuarter muda yang diindikasikan dengan skala warna yaitu lapisan batuan berwarna biru tua hingga biru muda dengan nilai resistivitas berkisar antara $6-40 \Omega \mathrm{m}$ merupakan jenis lapisan lempung berpasir, lapisan batuan yang berwarna hijau dengan nilai resistivitas berkisar antara $50-80 \Omega \mathrm{m}$ diindikasikan sebagai lapisan pasir dan untuk lapisan batuan dengan warna kuning sampai merah yang memiliki nilai resistivitas berkisar antara $100-400 \Omega \mathrm{m}$ merupakan jenis batupasir, breksi dan tufa.

Selanjutnya tampilan hasil inversi pengolahan data geolistrik pada lintasan 2, ditunjukkan pada gambar 7 berikut.

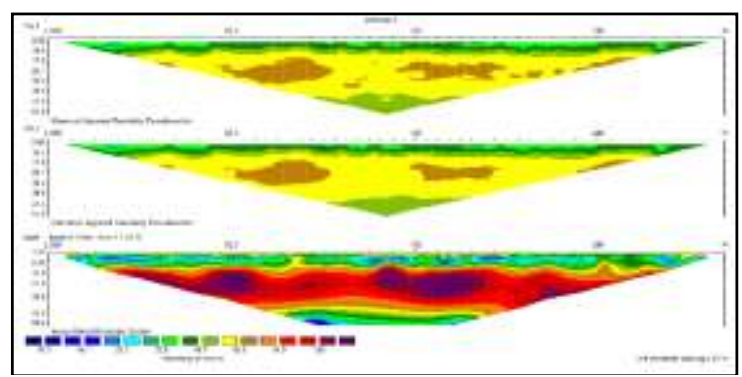

Gambar 7. Penampang 2D harga resistivitas semu dari hasil inversi lintasan 2. 
Penampang resistivitas yang ditampilkan pada gambar 7 memberikan nilai distribusi resistivitas bawah permukaan dengan nilai RMS Error sebesar 1,52\% yang selanjutnya dapat diinterpretasi untuk mengetahui jenis perlapisan batuan di bawah permukaan berdasarkan nilai resistivitas semu hasil inversi.

Hasil pengolahan data di lintasan 2 ini menampilkan nilai resistivitas yang berkisar antara $10-200 \Omega \mathrm{m}$. Hal ini menunjukkan bahwa di lintasan pengukuran ini memiliki struktur perlapisan batuan yang relatif lemah jika dilihat dari nilai resistivitasnya yang rendah. Skala warna yang ditunjukkan yakni warna biru tua hingga warna biru muda dengan nilai resistivitas berkisar antara $10-25 \Omega \mathrm{m}$ merupakan lapisan lempung berpasir, lapisan batuan yang berwarna hijau dengan nilai resistivitas berkisar antara $30-60 \Omega m$ diindikasikan sebagai lapisan pasir dan untuk lapisan batuan dengan warna kuning sampai merah yang memiliki nilai resistivitas berkisar antara $60-200 \Omega \mathrm{m}$ merupakan jenis batupasir, breksi dan tufa.

Hasil ini dapat juga memperlihatkan bahwa struktur perlapisan batuan di lintasan 2 ini memiliki karakteristik yang identik dengan struktur perlapisan batuan yang ada pada lintasan 1, dimana nilai resistivitas hasil inversi yang diperoleh setelah melakukan pengolahan data memiliki harga yang tidak mengalami perbedaan secara signifikan meskipun berada pada titik pengukuran yang relatif berjauhan dan terpisah oleh satu jalur sungai.

\section{Kesimpulan}

Berdasarkan pengolahan dan analisis data hasil penelitian yang telah dilakukan, maka dapat disimpulkan bahwa terdapat zona sesar di daerah penelitian berdasarkan interpretasi penampang 2D dari data hasil inversi nilai resistivitas yang diperoleh menggunakan metode geolistrik, dimana struktur perlapisan batuan antara lintasan 1 dan lintasan 2 memiliki karakteristik yang identik sehingga mengindikasikan keterdapatan aktivitas sesar mendatar yang telah memisahkan kedua bidang tersebut.

Struktur geologi yang dapat diamati terkait aktivitas sesar di daerah penelitian adalah adanya kenampakan gawir sesar, terbentuknya lembah Sungai Bijawang, penurunan bidang daratan yang membentuk bidang horst dan graben. Adanya pembelokan yang cukup tajam pada alur sungai dan gawir sesar yang terdapat di sepanjang lembah pada jalur sungai dapat diindikasikan sebagai akibat adanya aktivitas sesar mendatar pada area tersebut

\section{Daftar Pustaka}

BMKG. Katalog Gempabumi. Badan Meteorologi dan Klimatologi dan Geofisika. 21 November 2018. http://repogempa.bmkg.go.id/repo new/index.php

Bock, Y., Prawirodirdjo, L., Genrich, J.F., Stevens, C.W., McCaffrey, R., Subarya, C., Puntodewo, S.S.O., Calais, E. 2003. Crustal motion in Indonesia from Global Positioning System measurements. Journal of Geophysical Research, Vol. 108, No. B8, 2367.

Hamilton, Warren. 1979. Tectonics of the Indonesian Region. Washington: Geological Survey Profesional Paper 1078.

Massinai, M.F.I. 2016. Aplikasi Double Difference untuk Penentuan Lokasi Hiposenter Secara Akurat pada Zona Sesar Palu Koro menggunakan Data Korelasi Silang Waveform. Tesis Program Studi Teknik Geofisika. ITB: Bandung.

Massinai, M.A., Saaduddin, Massinai, M.F.I. 2017. Kajian Daerah Rawan Gempa di Bulukumba, Sulawesi Selatan. Jurnal Geocelebes Vol. 1 No. 1, April 2017, 30 - 37. 
Natawidjaya, D. H. dan Triyoso, W., 2007.

The Sumatran Fault Zone - from

Source to Hazard. Journal of Earthquake and Tsunami, Vol. 1, No. $1,21-47$.

Pakpahan, Suliyanti, Ngadmanto Drajat, Masturyono. 2015. Analisis Kegempaan di Zona Sesar Palu Koro, Sulawesi Tengah. Jurnal Lingkungan dan Bencana Geologi, Vol. 6 No. 3, Desember 2015: 253 -264 .

Pertiwi, I. I., Fattah M. Hattah, Rauf Abdul. 2017. Estimasi Kawasan Terdampak Tsunami dan Mitigasi Bencana Kabupaten Bulukumba, Indonesia. Jurnal Geofisika Vol. 16, No.01 pp. $01-08$.

Sukamto Rab, Supriatna Sam. 1982. Peta Geologi lembar Ujung Pandang, Benteng dan Sinjai. Jakarta: Pusat Penelitian dan Pengembangan Geologi. 